\title{
The role of affordances in developing children manipulative movement skills: an application of challenge point framework
}

Balali, M. (Ph.D. Candidate). Islamic Azad University, Science and Research Branch, Tehran, Iran

Vaez Moosavi, S, M, K. (Ph.D). Imam Hossein University, Tehran, Iran

Ghasemi, A. (Ph.D). Islamic Azad University, Science and Research Branch, Tehran, Iran

\section{Abstract:}

The purpose of present study was to investigate predictions of challenge point theory (guadagnoli and lee, 2004) through comparing two group of challenging and nonchallenging games in developing manipulative fundamental movement skills. Thirty 4 to 6 years old child were selected from one of the kindergartens of Tehran and were grouped according to pretest scores. The games were used were designed for developing manipulative skills in both groups, however the task difficulty of these games was increased in challenging group while in nonchallenging group it was kept constant. The intervention was 8 weeks, 2 session for each week and 42 minutes for each session. Children's manipulative skills were assessed using Test of Gross Motor Development - second version in the beginning and the end of the intervention. The results of multivariate analysis of variance showed that improvement groups in total score of manipulative skills and all subscales exept that catching wasn't significant. In total, if the challenge point theories predictions on developing of manipulative skills of healthy children failed to be proved but better improvement of challenging group in catching shows that this method is more effective in developing complex skills.

Keywords: Play, Functional Task Difficulty, Kindergarten, Motor Learning 


\title{
نقش فراهمسازها در رشد مهارتهاى حر كتى بنيادى دستكارى كودكان: كاربردى از جارجوب نظرى نقطه جالش
}

\author{
مرضيه بلالى *، سيد محمد كاظم واعظ موسوى ا***، عبدالله قاسمى **

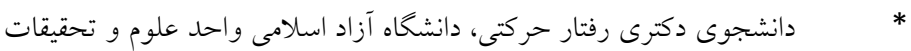

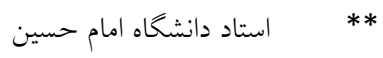 \\ دانشيار دانشخاه آزاد اسلامى واحد علوم و تحقيقات
}

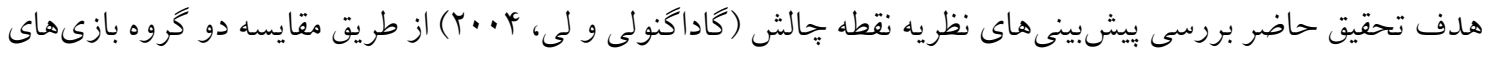

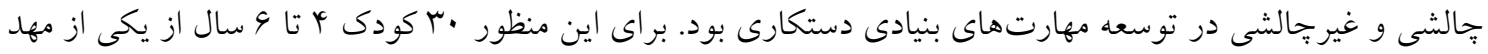

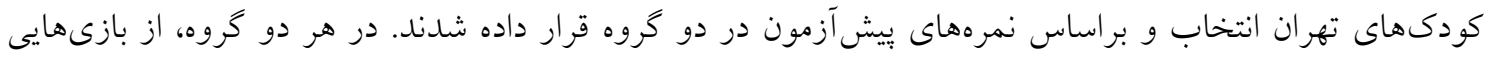

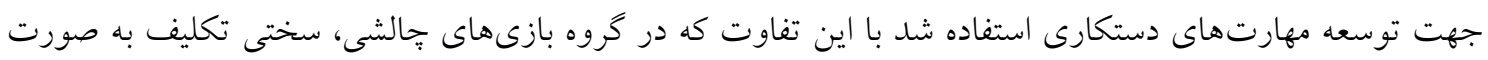

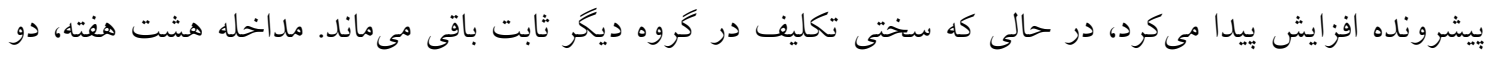

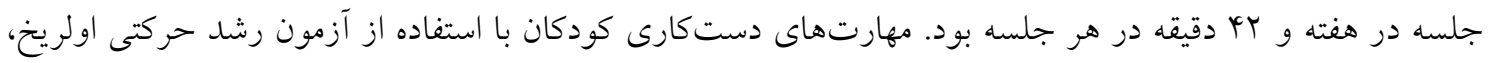

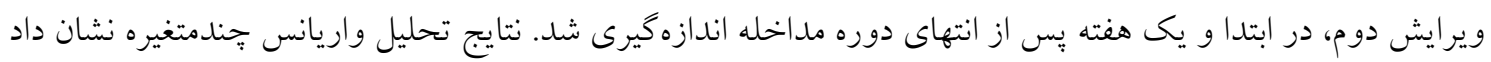

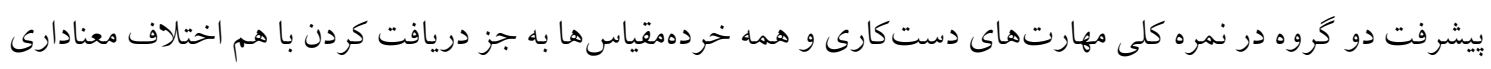

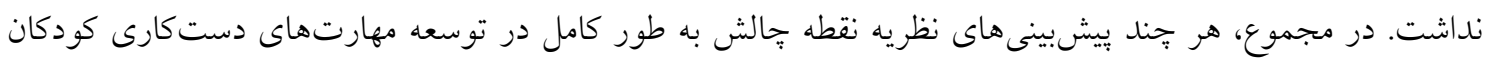

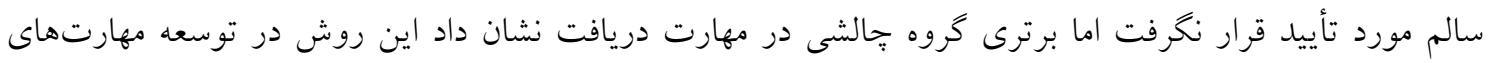

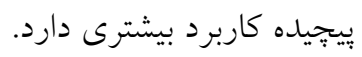
وازههاى كليدى: بازى، سختى تكليف كاركردى، مهد كودى، يادئيرى حركتى. 
تبحر در مهارتهاى حركتى بنيادى در كودكى كفايت حركتى، مشاركت ورزشى، زندكى فعال، رشد شناختى و بيش كيرى از خاقى

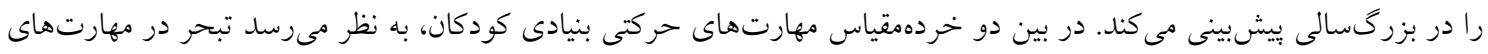

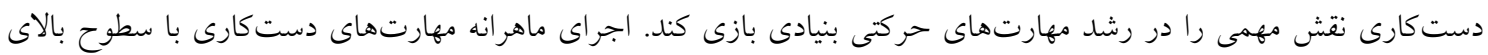

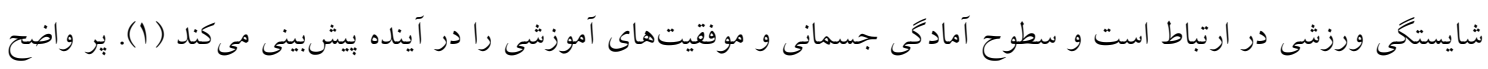

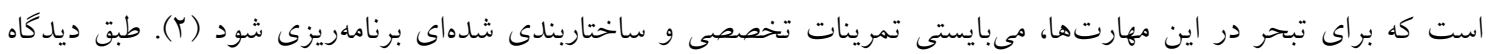

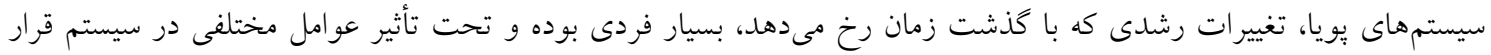

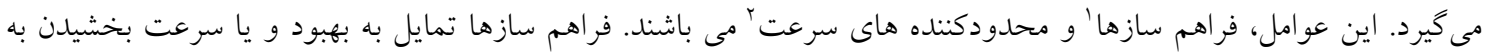

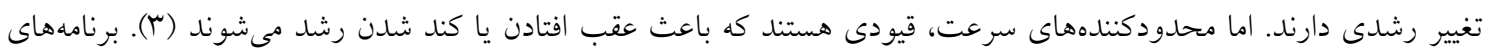

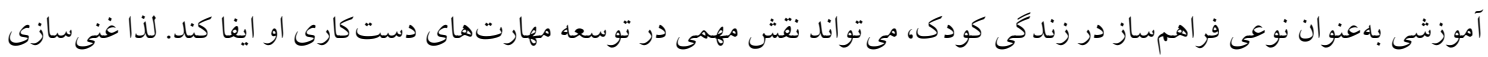

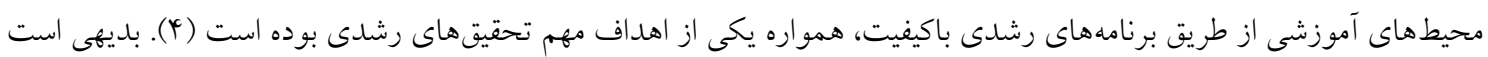

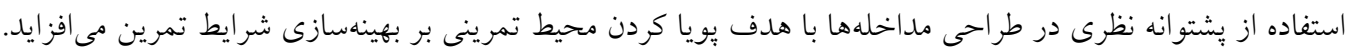

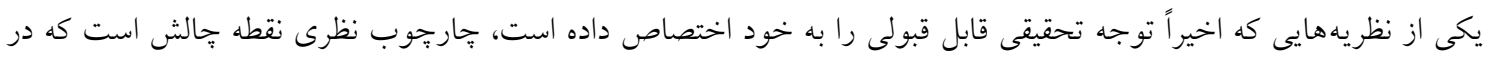

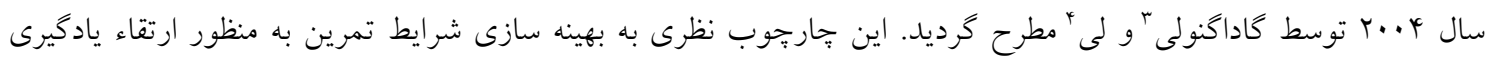

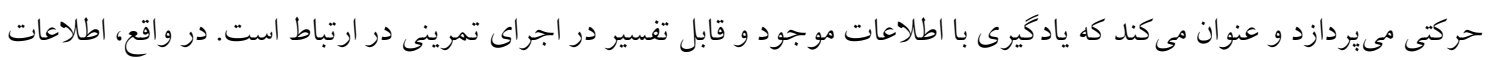

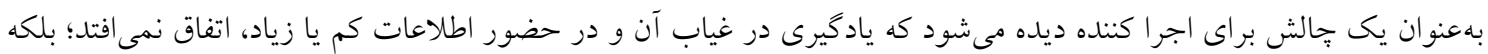

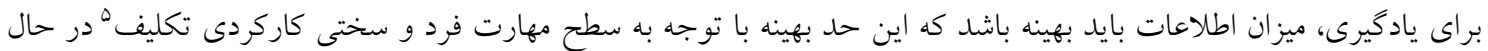
يادكيرى متغير است (ه). سختى كاركردى تكليف بهعنوان جالش شناختى يا بدنى كه بهوسيلة يك مسئله حركتى مطرح مى بروده،

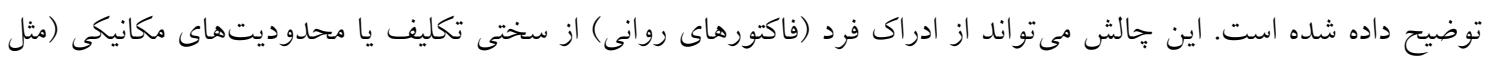

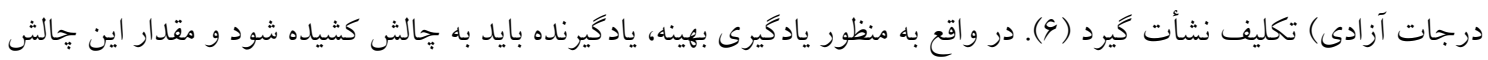

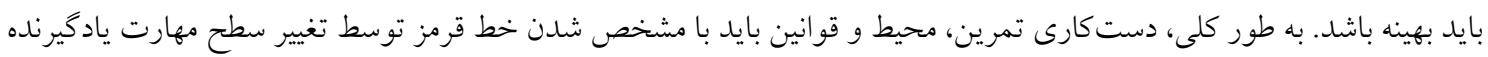

و سختى كاركردى تكليف صورت بذيرد تا تغيير شرايط تمرين موجب جالشى شدن و يادگيرى بهينه شود نه اجراى بهينه (9).

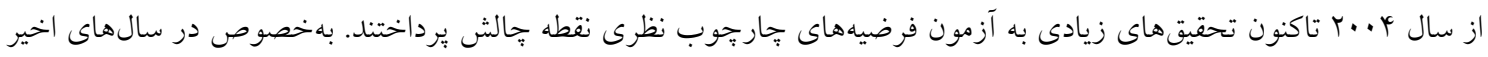

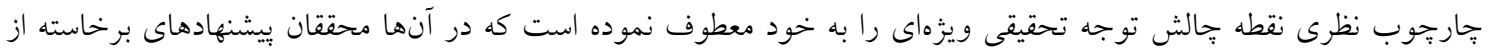

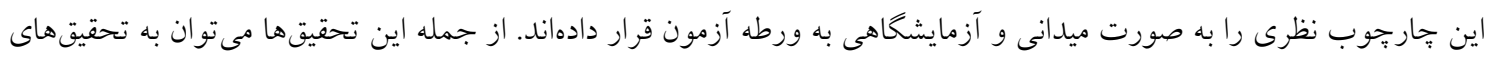

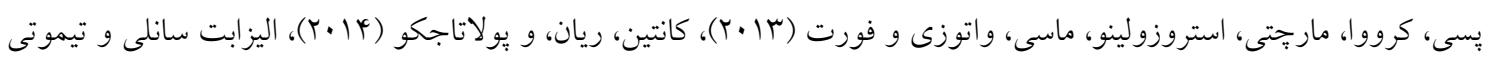

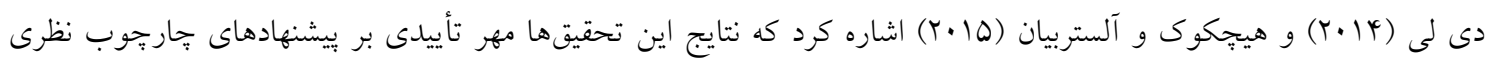

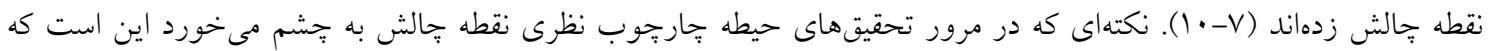

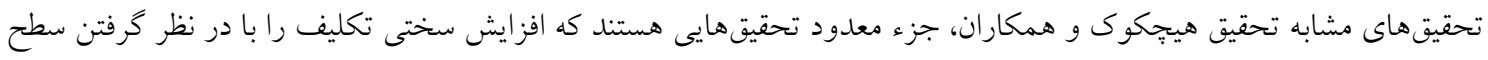

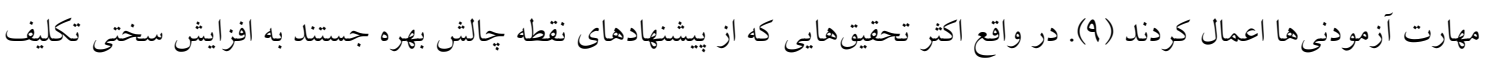

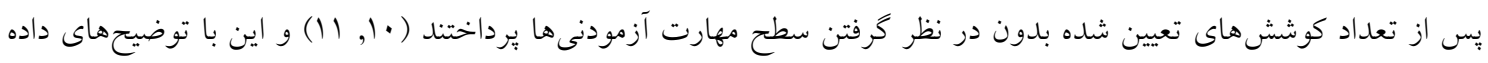

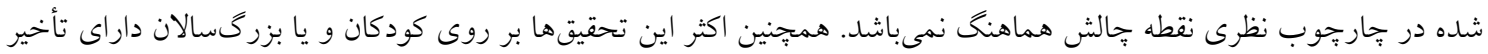

رشدى يا مشكل حركنى انجام شده است (v, ^).

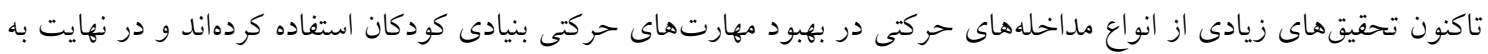

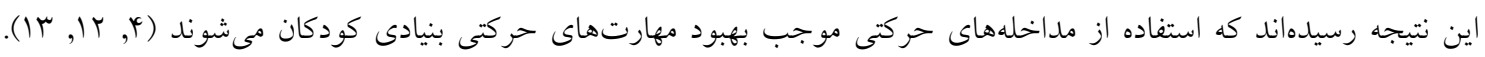

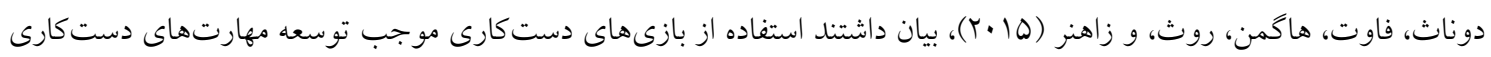


دريافت كردن و دريبل كردن شده، اما در مهارتهاى يُرتاب بالاى سر، شوت كردن و غلتاندن توب، بهبود به وجود نيامده است (Y I ). با توجه به شمار زياد مطالعهها در زمينه اثر انواع مداخلهها در توسعه مهارتهاى حركتى بنيادى دستكارى، تاكنون تنها

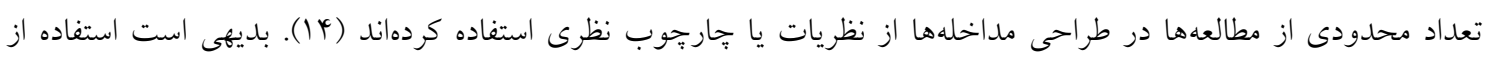
يشتوانه نظرى در طر احى مداخلهها با هدف يويا كردن محيطهاى تمرينى بر بهينهسازى شرايط تمرين مى افزايد.

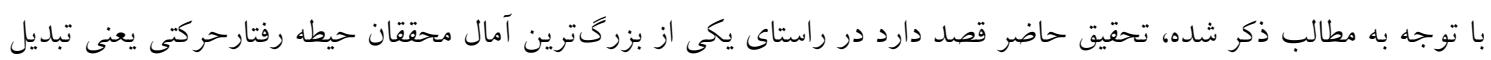

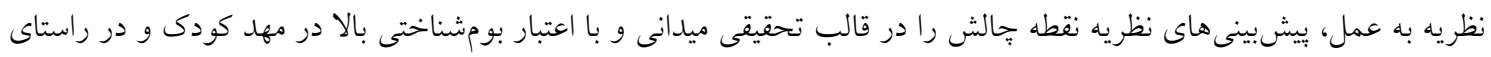

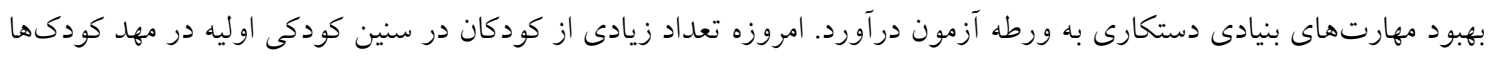

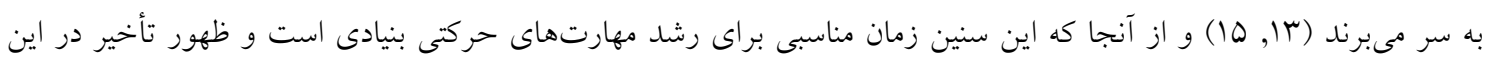
مهارتها در اين سنين كزارش شده است، اين مراكز، محيطهاى مناسبى براى تسهيلسازى شايستكى مهارتهاى حركتى بنيادى

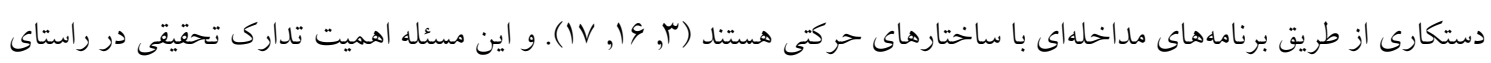
كشف روشهاى تمرينى بهينه بر اساس جديدترين نظريههاى ياد كيرى حركتى را روشنتر مىسازد.

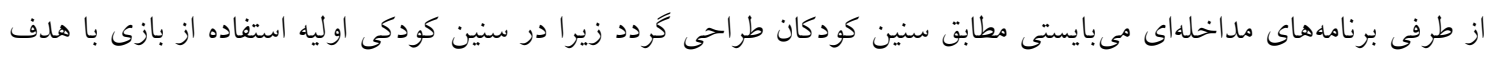
لذت بردن بسيار مفيد خواهد بود و مى تواند در بويايى محيط تمرينى و بهينهسازى شرايط تمرين در مهل كودى نقش مفيدى مفيدى داشته

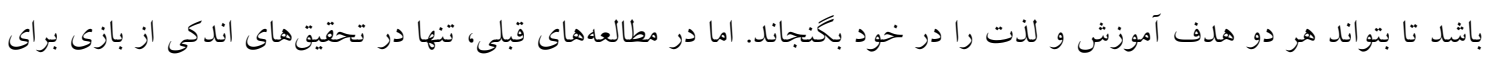
مداخله استفاده شده است و در صورت استفاده از بازى در مورد طراحى دقيق بازىها يا زمان هر يكى از بازىها توضيحى ارائه

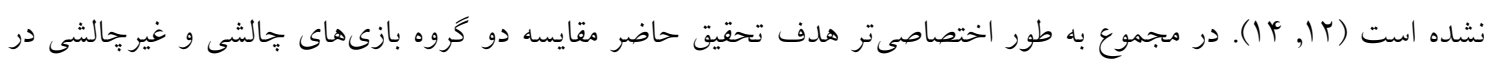
بهبود مهارت هاى بنيادى دستكارى كودكان أ تا 9 سال مىباشد. فرضيه تحقيق حاضر بر اساس ادبيات بيشينه بيشرفت بيشتر كروه بروه

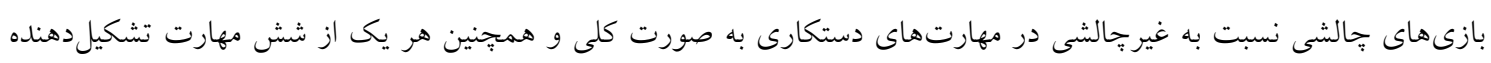

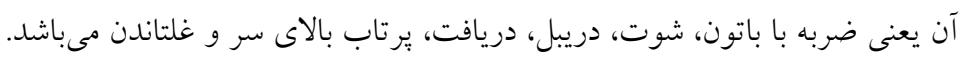

روش

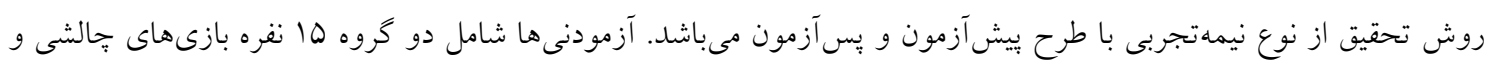

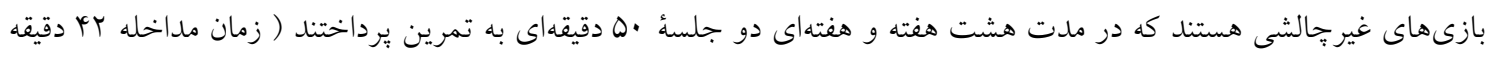
در هر جلسه). يكى هفته يُ از اتمام جلسههاى تمرينى از كودكان يس آزمون ياددارى كرفته شد. جامعه آمارى تحقيق، كليه كودكان

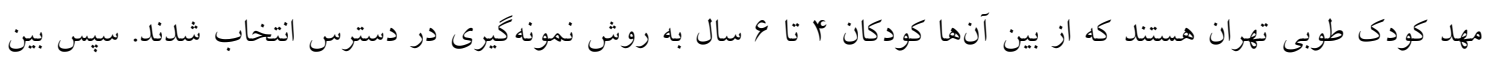

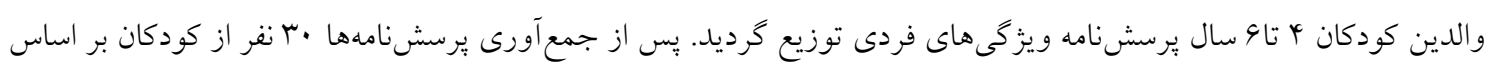
سؤالات يرسشنامه و اهداف طرح انتخاب شدند. متغير وابسته، مهارتهاى حركتى بنيادى دستكارى كودكان مىباشد كه از طريق آزمون رشد حركتى درشت ويرايش دوم، قبل و

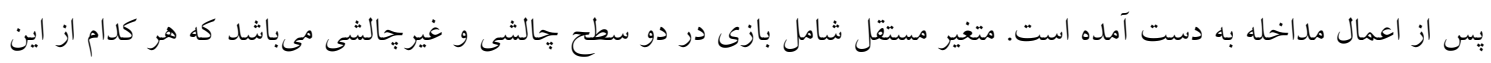

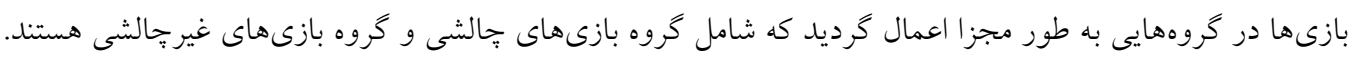

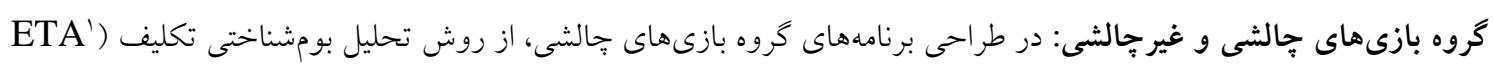

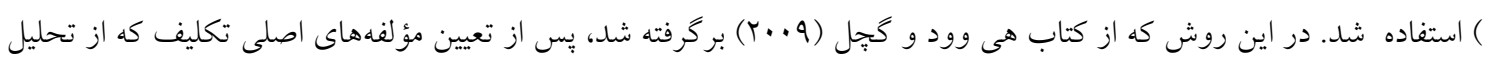
قيود تكليفى و محيطى اثركذار در ميزان دشوارى تكليف حاصل مىشود، مربى با دستكارى ميزان سختى تكليف، آنها را با توجه به قيود فردى متناسب مى سازد. به نحوى كه با بيشرفت آزمودنى ها در تكليفهاى مورد نظر، محيط و شرايط بازى نيز با دستكارى

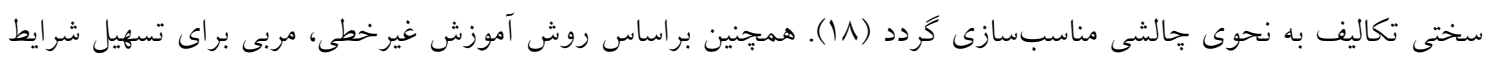

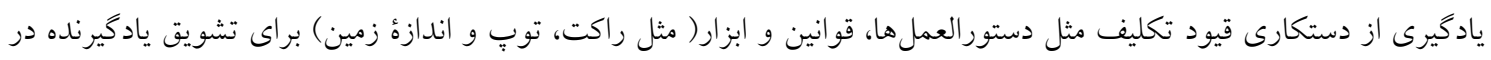

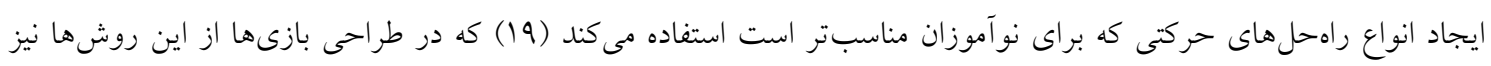

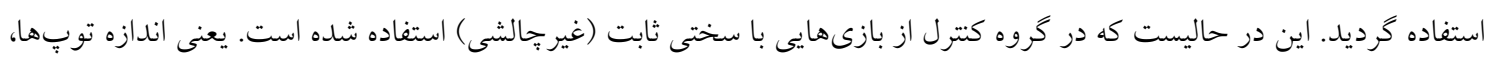


فاصله ها، سطح مقطع، هدف و قوانين در طول دوره تمرين ثابت ماند. در واقع تفاوت بين دو گروه در تغيير شرايط بازى بود. در

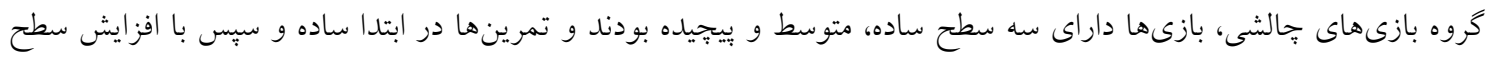

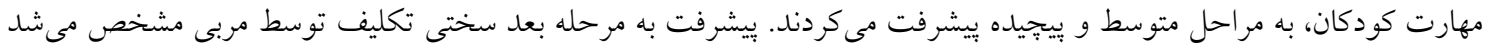

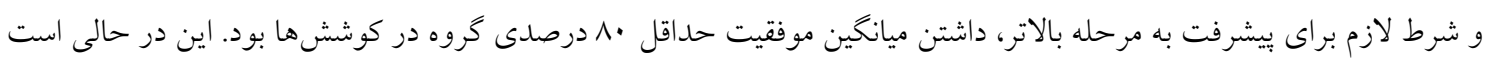

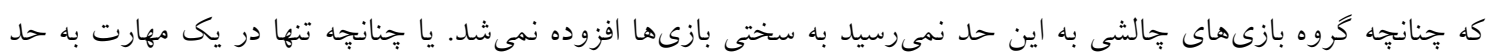
مورد نظر رسيد تنها جالش آن بازى افزايش مىيافت. استفاده از ميانخين سه سطح و تعيين درصد موفقيت براى صعود به مرحله بهائه

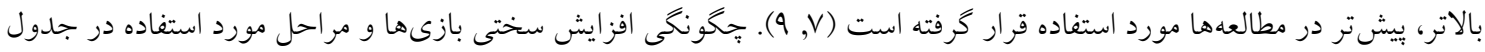

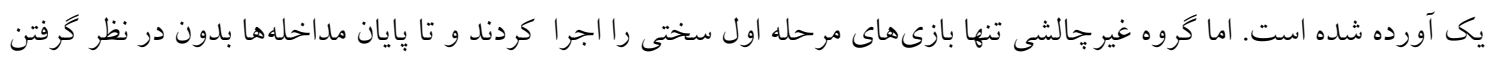

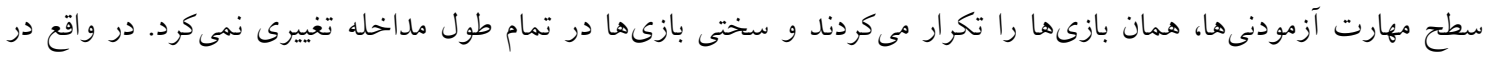

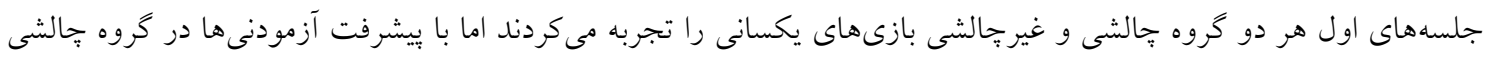
سختى تكليف افزايش داده مى شد.

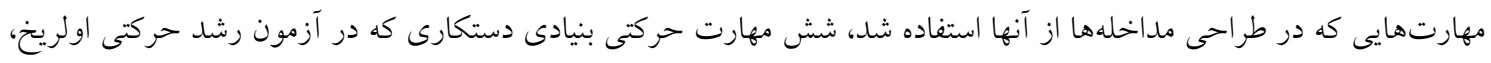

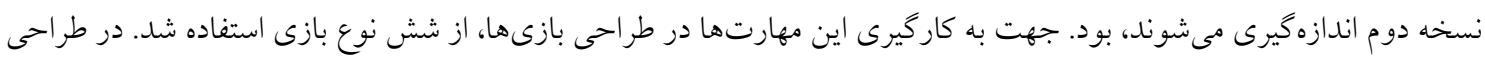

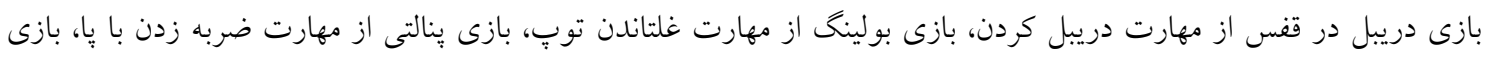

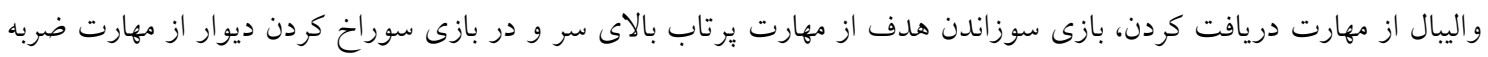
زدن با باتون استفاده شد. نحوه انجام بازىها طورى بود كه در هر جلسه، هر بازى مدت هفت دقيقه به طول انجاميد.

جدول ا. جكونغى افزايش خالش در بازىهاى گروه بازىهاى جالشى

\begin{tabular}{|c|c|c|c|}
\hline سطح r - ( & سطح r & سطح 1 & بازىها \\
\hline 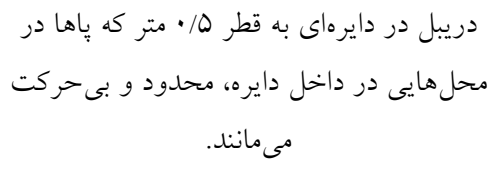 & دريبل در دايرهاى به قطر ه/• & دريبل در دايرهاى با قطر 1/ه & دريبل در قفس \\
\hline غلتاندن توب به سمت r بولينگ & 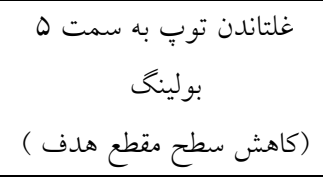 & غلتاندن توب به سمت 1 بولينح & 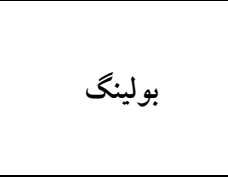 \\
\hline ضربه به توب ثابت از فاصله ه مترى & ضربه به تو ثَ ثابت از فاصله & 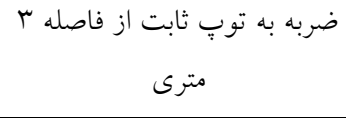 & 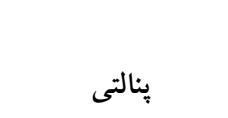 \\
\hline 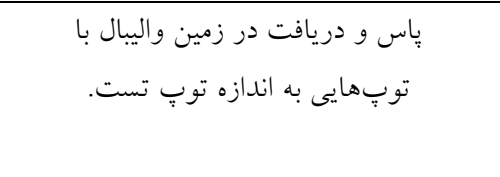 & 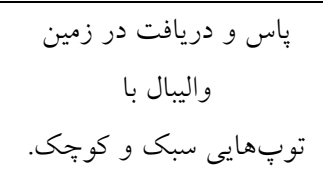 & 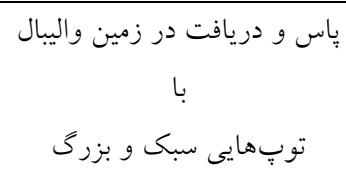 & 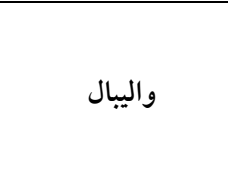 \\
\hline 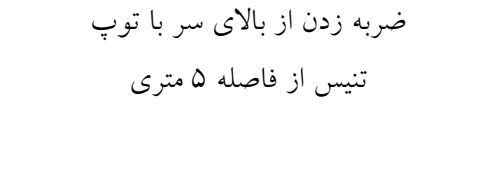 & ضربه زدن از بالاى سر با & ضنيس زدن از بالاى سر با تو تِ & سوزاندن هدف \\
\hline 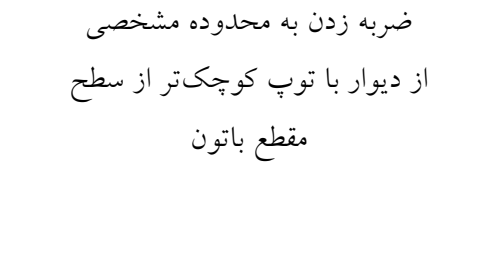 & 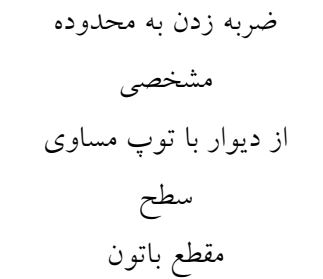 & ضربه زدن به محدوده مشخصى ديو & سوراخ كردن ديوار \\
\hline
\end{tabular}


ابزار جمع آورى دادهها: براى سنجش آزمودنىها در بيش آزمون و پِسآزمون از آزمون رشد حركتى درشت اولريخ ويرايش دوم

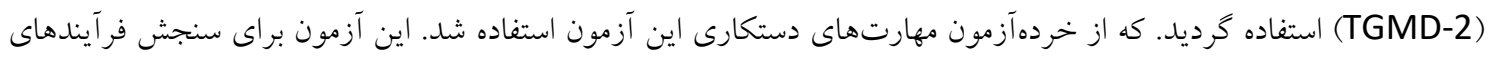

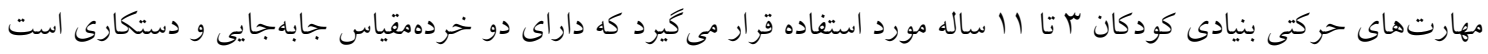

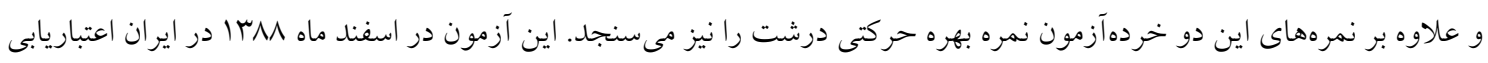

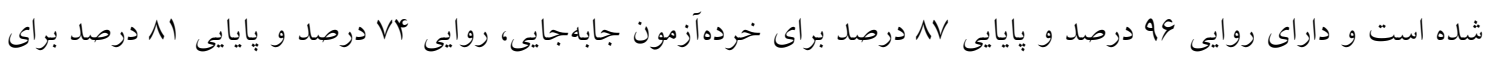

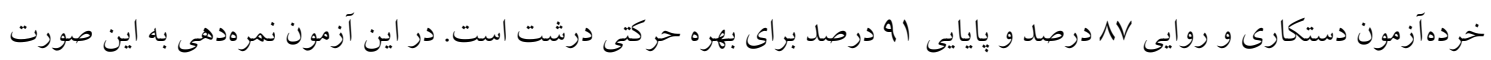

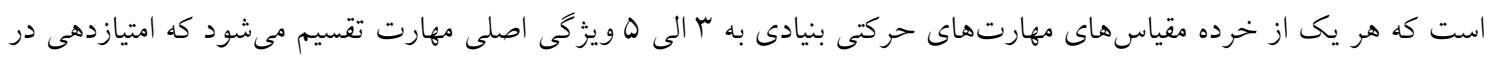

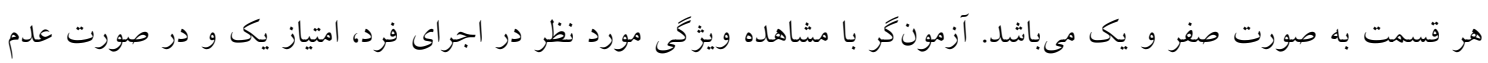

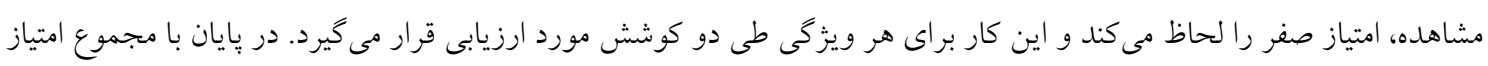

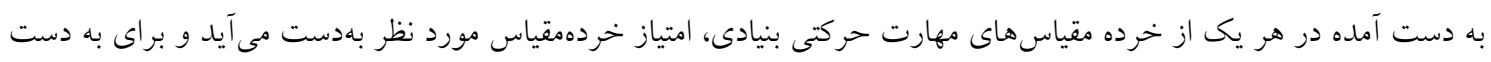

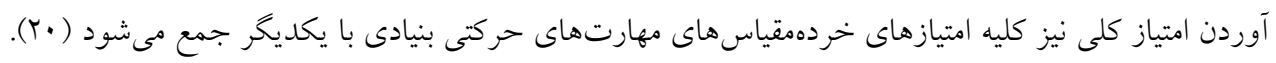

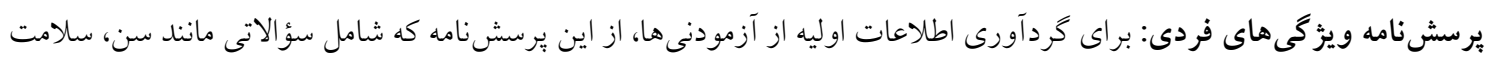

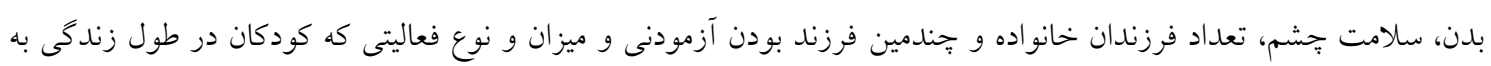

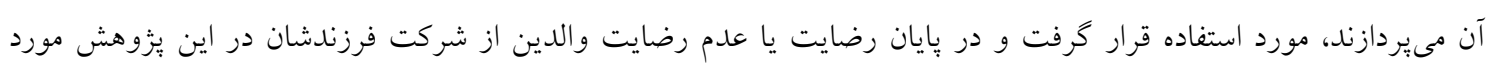
ئرسش قرار كرفت.

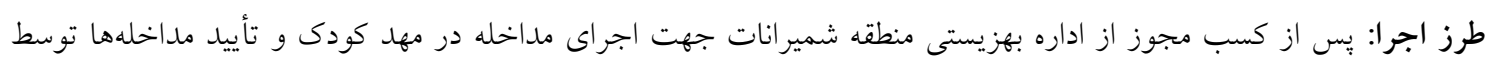

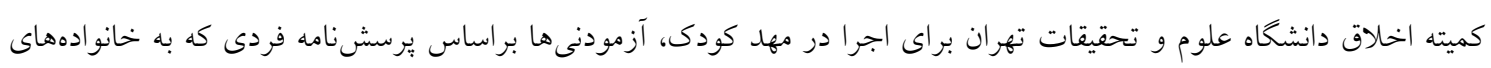

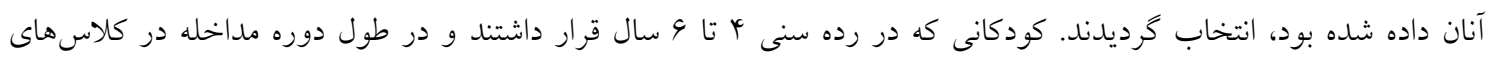

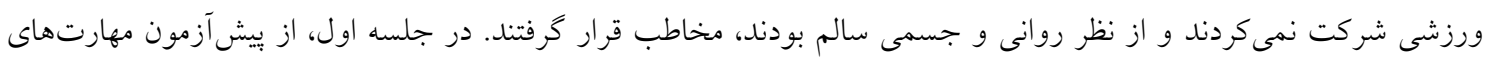

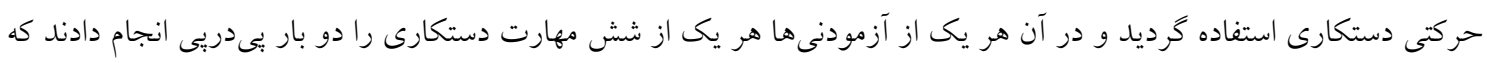

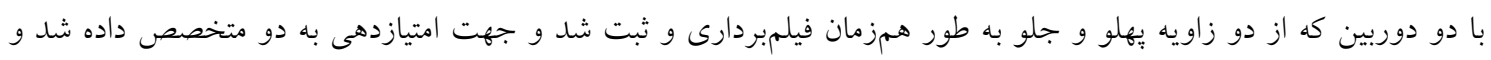

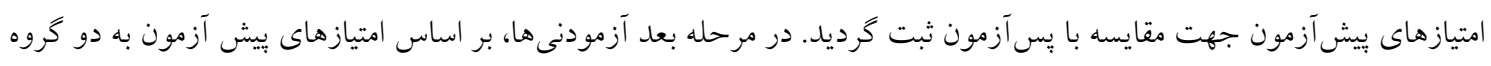

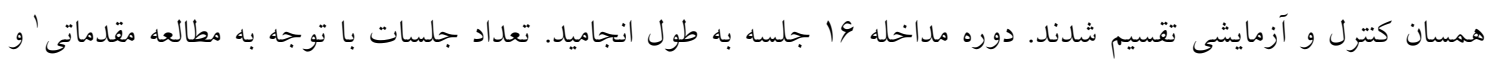

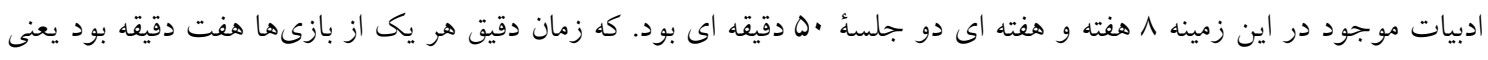

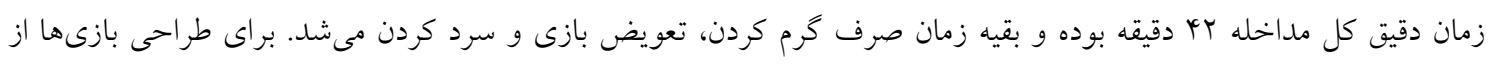

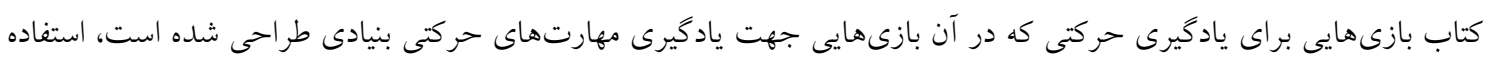

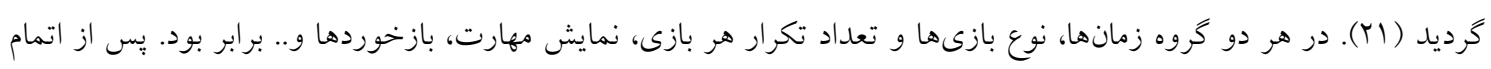

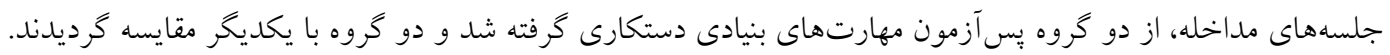

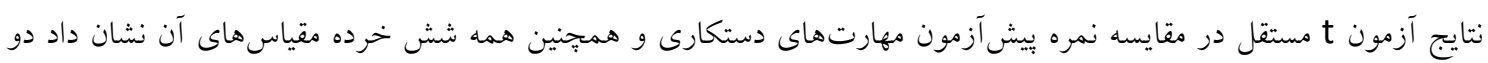

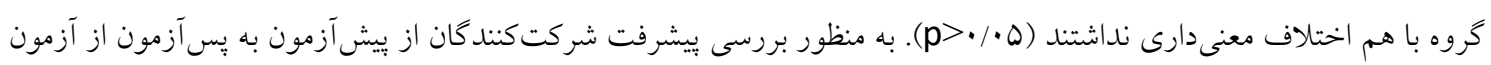

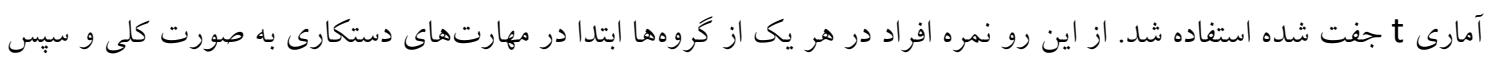

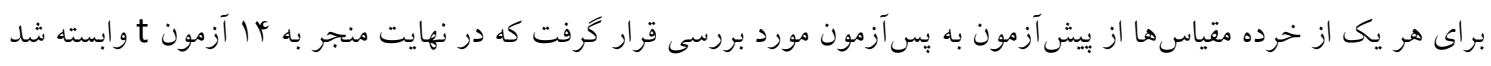

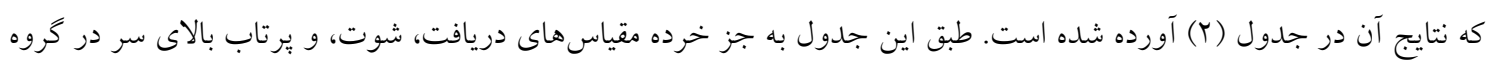

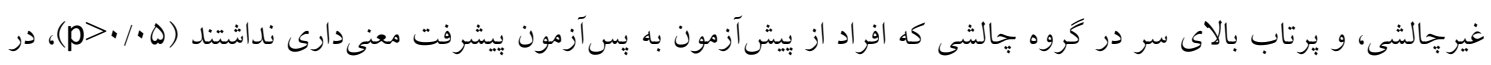

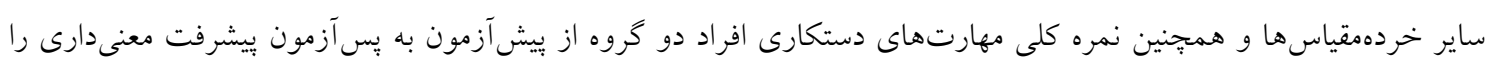

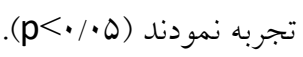




\begin{tabular}{|c|c|c|c|c|c|c|}
\hline \multirow[b]{2}{*}{ معنى دارى } & \multirow[b]{2}{*}{ درجات آزادى } & \multirow[b]{2}{*}{$\mathbf{t}$} & \multicolumn{2}{|c|}{ اختلاف جفتها } & \multirow[b]{2}{*}{ كروه } & \multirow[b]{2}{*}{ متغير } \\
\hline & & & انحر اف استاندارد & ميانكين & & \\
\hline$\cdot / \cdot$ & 14 & $\begin{array}{l}-1 \cdot 199 \\
-0 / v 9\end{array}$ & $\begin{array}{l}Y / T Q \\
Q / Q T\end{array}$ & $\begin{array}{l}-11 / N \mu \\
-\Lambda / Y 9\end{array}$ & بازى بازى غاى پالشى غيالشى & مهارتهاى دستكارى \\
\hline $\begin{array}{l}\cdot / \cdot r \\
\cdot / \cdot\end{array}$ & 14 & $\begin{array}{l}-T / 9 Y \\
-Y / T \Lambda\end{array}$ & $\begin{array}{l}\text { T/TG } \\
T / T H\end{array}$ & $\begin{array}{l}-1 / 0 r \\
-r / \cdot 9\end{array}$ & بازى باى هاى پالشى غير پالشى & مهارت ضربه با باتون \\
\hline $\begin{array}{l}\cdot / \cdot \\
. /\end{array}$ & 14 & $\begin{array}{l}-V / N I \\
-Y / 4 Y\end{array}$ & $\begin{array}{l}r / \mathcal{E V} \\
T / Q 1\end{array}$ & $\begin{array}{c}-0 \\
-\mu / \mu\end{array}$ & بازى هاى هاى غالشى غير & مهارت دريبل \\
\hline $\begin{array}{l}\cdot / \cdots \\
\cdot / r q\end{array}$ & 14 & $\begin{array}{l}-0 / 79 \\
-1 / \cdot 9\end{array}$ & $\begin{array}{l}1 / 90 \\
T / 1 T\end{array}$ & $\begin{array}{l}-r / 94 \\
-\cdot / 9\end{array}$ & 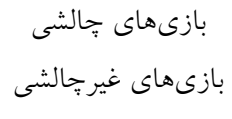 & مهارت دريافت \\
\hline $\begin{array}{l}\cdot / \cdot r \\
\cdot / 41\end{array}$ & 14 & $\begin{array}{l}-r / 4 Y \\
-\cdot / A r\end{array}$ & $\begin{array}{l}1 / 49 \\
1 / 04\end{array}$ & $\begin{array}{l}-0 / \Lambda \\
-0 / \mu\end{array}$ & بازى باى هاى غالشى غالشى & مهارت شوت \\
\hline $\begin{array}{lll}\cdot / \cdot \Lambda \\
\cdot / r\end{array}$ & 14 & $\begin{array}{l}-1 / 20 \\
-1 / 49\end{array}$ & $\begin{array}{l}1 / \Delta T \\
r / 4 \Delta\end{array}$ & $\begin{array}{l}-\cdot / N r \\
-\cdot / \Lambda\end{array}$ & بازى باى هاى پالشى غالشى & مهارت يرتاب بالاى \\
\hline $\begin{array}{l}\cdot / \cdot 1 \\
\cdot / \cdot 1\end{array}$ & If & $\begin{array}{l}-Y / 94 \\
-Y / 91\end{array}$ & $\begin{array}{l}1 / 49 \\
1 / 14\end{array}$ & $\begin{array}{c}-1 \\
-\cdot / 19\end{array}$ & بازى باى باى جالشى غير جالشى & مهارت غلتاندن \\
\hline
\end{tabular}

به منظور بررسى اختلاف دو گروه در متغيرهاى وابسته با استفاده از آزمون آمارى تحليل واريانس خجندمتغيره از روش تحليل

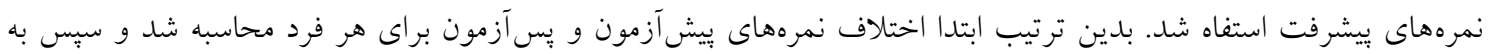

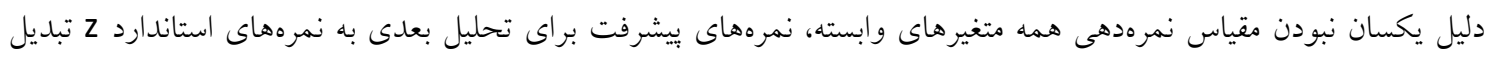

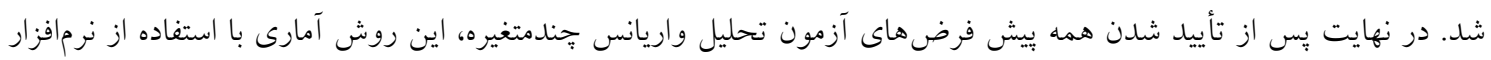
آمارى Spss نسخه آب انجام شد.

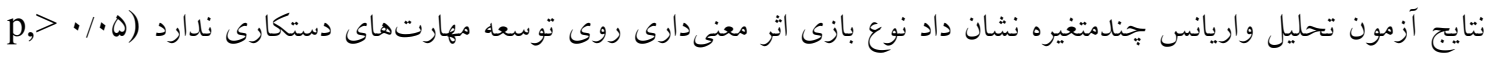

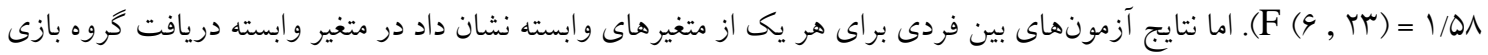

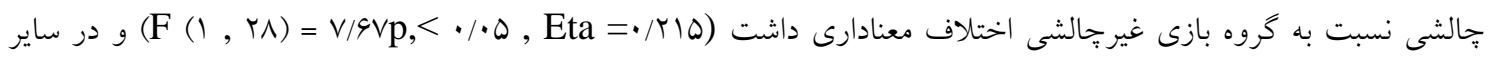

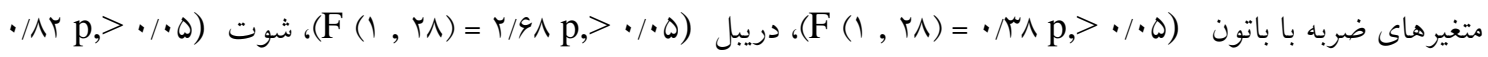

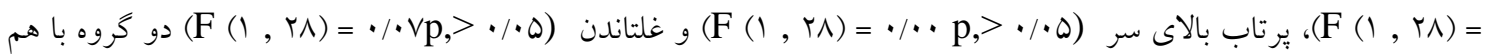


نمودار ا. مقايسه ميانگين نمرههاى افراد دو گروه جالشى و غير جالشى در نمره كلى مهارتهاى دستكارى و خرده مقياس هاى مهارت هاى دستكارى در بيش آزمون و يس آزمون

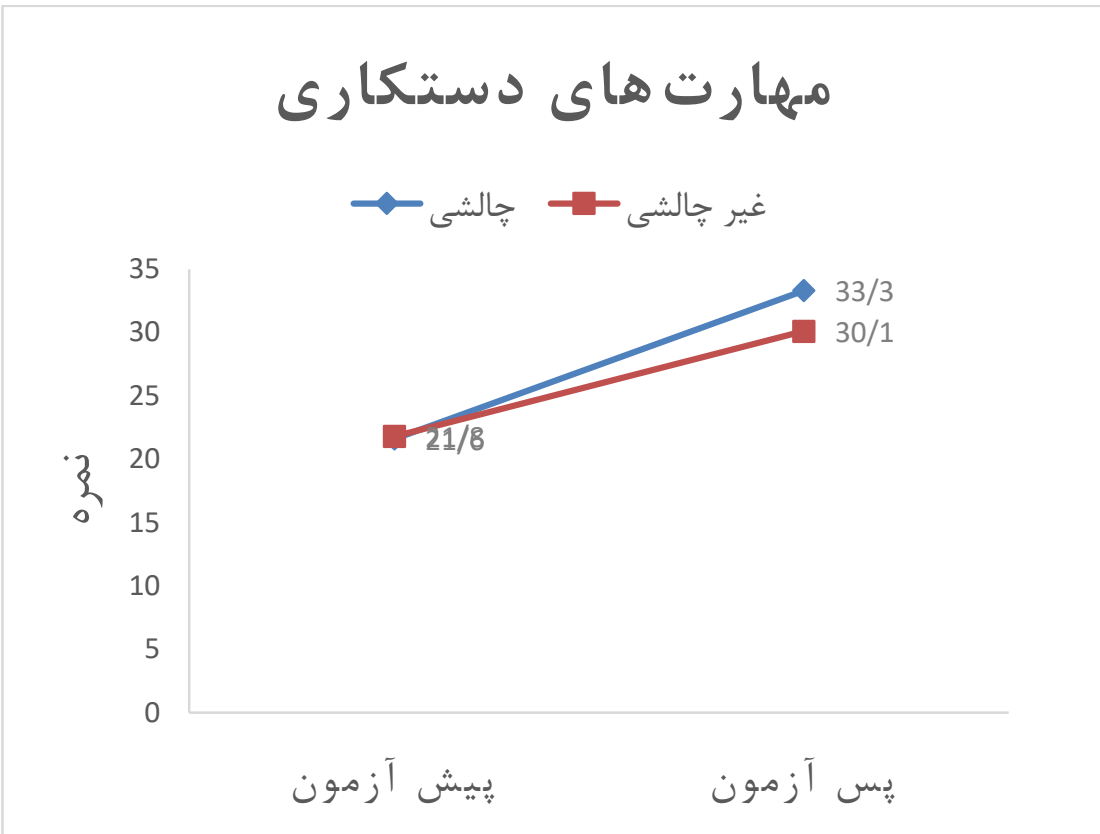




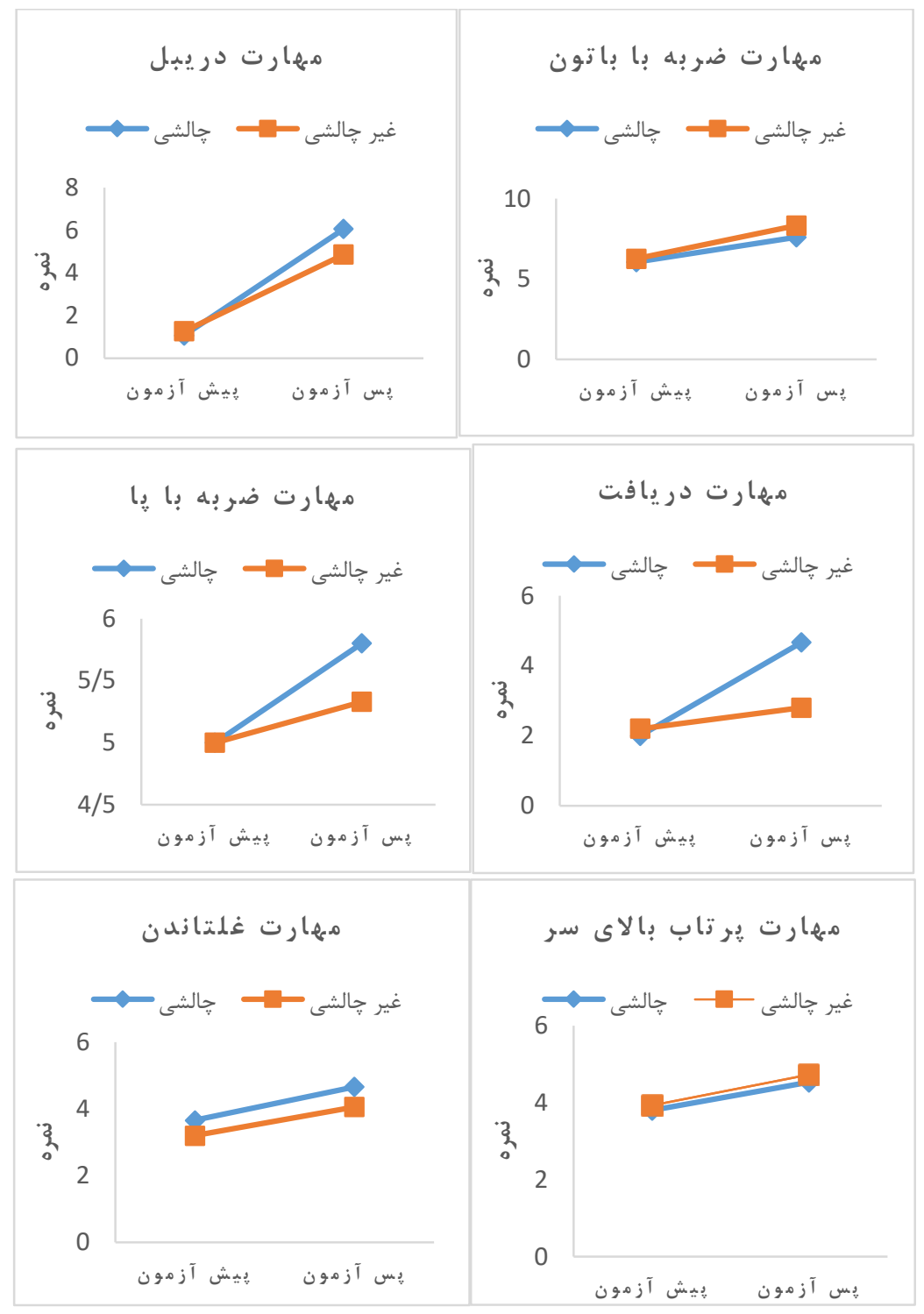

بحث و نتيجه تيرى

هدف تحقيق حاضر بررسى صحت ييشبينىهاى خارجوب نظرى نقطه خالش در يكى محيط يويا (مها كودى) و بر توسعه

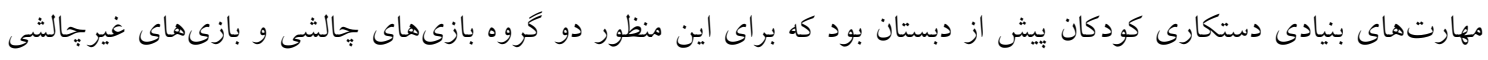

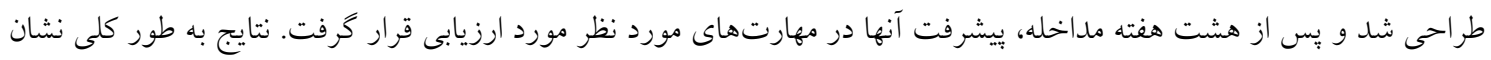

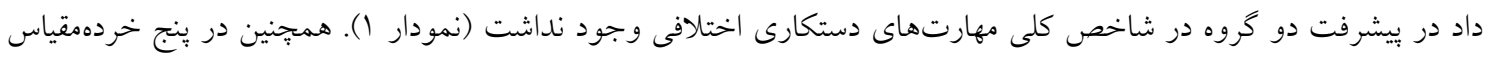

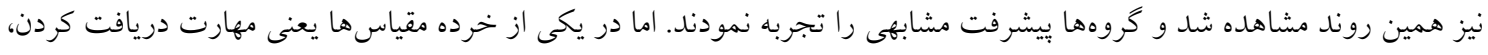

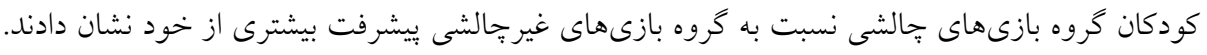

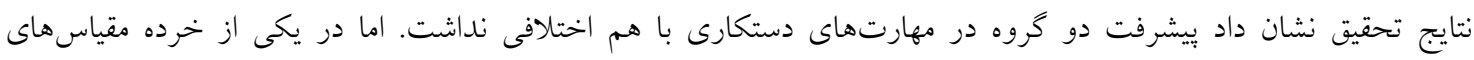

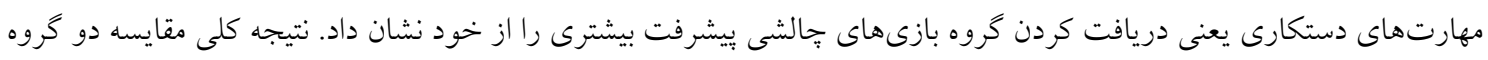

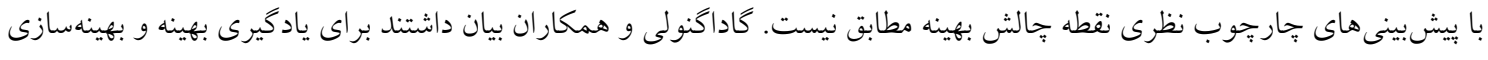

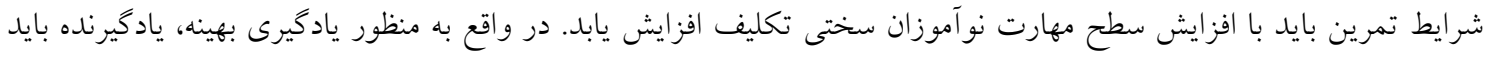

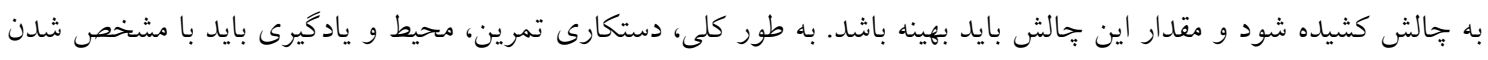

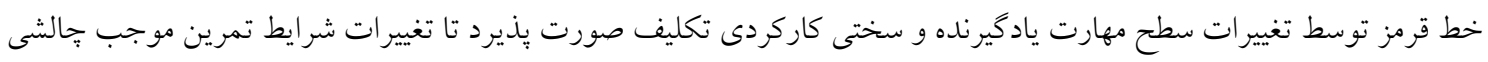

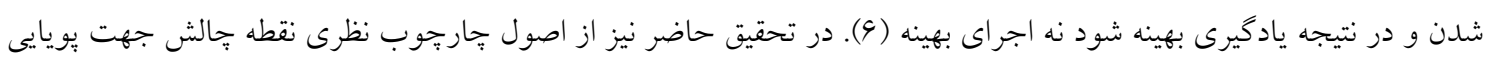


محيط و افزايش ميزان ياد گيرى استفاده شد. يعنى با افزايش سطح مهارت كودكان به سختى تكليف افزوده مىشد اما نتايج تحقيق

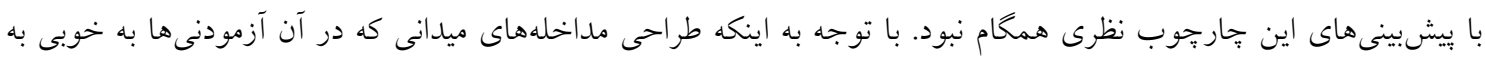

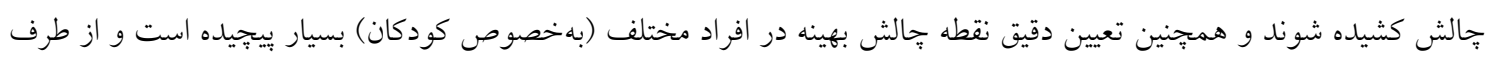

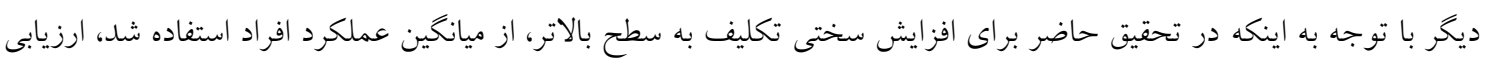
دقيق به جالش كشيده شدن افراد ممكن نبود. يكى ديكر از عواملى كه ممكن است موجب مشتبه شدن نتايج شده باشد، استفاده از

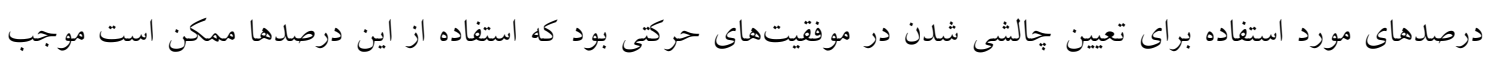
جالشى شدن بهينه كودكان نشده باشد. لذا حدس محققان اين است كه دليل عدم برترى كروه جالشى نسبت به غيرجّالشى شايد

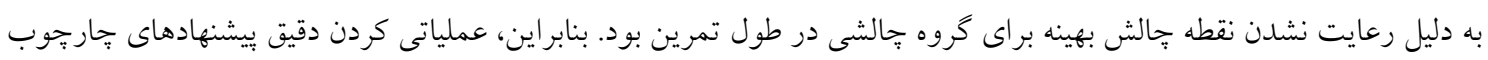

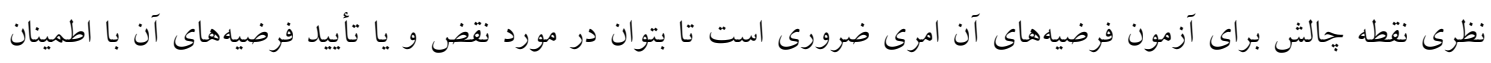
بيشترى سخن كفت. اين نتيجه با تحقيق اليزابت سانلى و همكاران (T/ (Y) نقاط مشتركى دارد. سانلى و همكاران بيان كردند كه گروهى كه در تمرينات

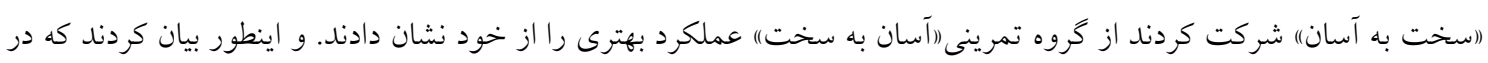
كروه سخت به آسان نسبت به گروه آسان به سخت نقطه جالث بهينه حفظ گشته و يادگيرى صورت گرفته است. در تحقيق حاضر

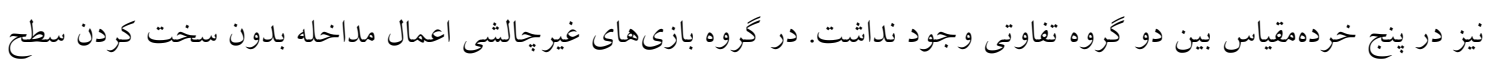

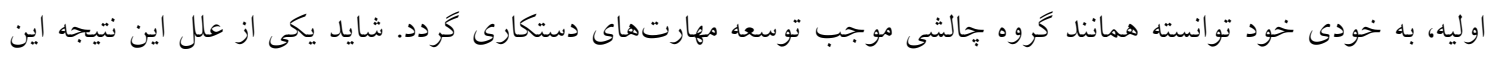

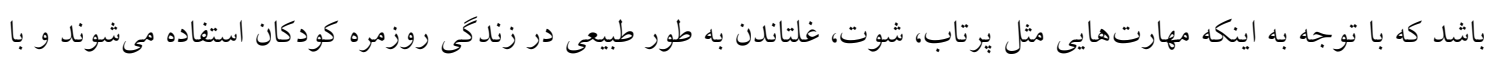

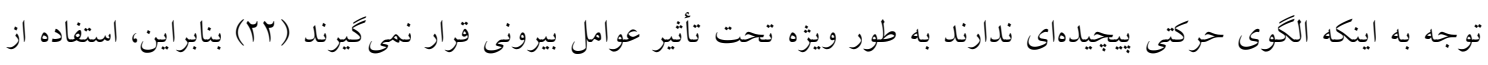

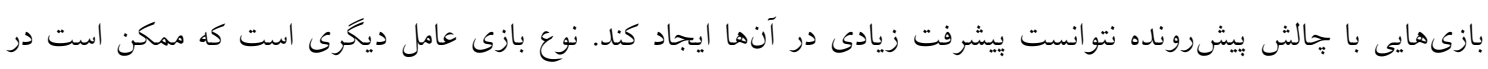

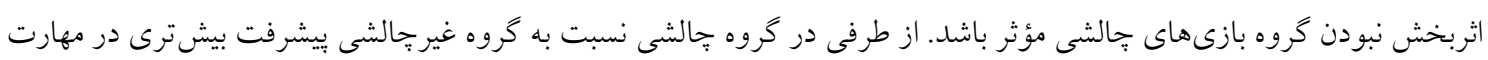

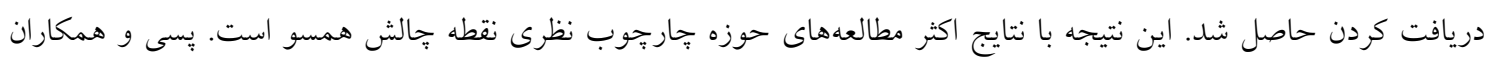

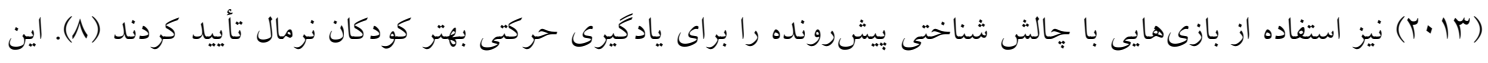

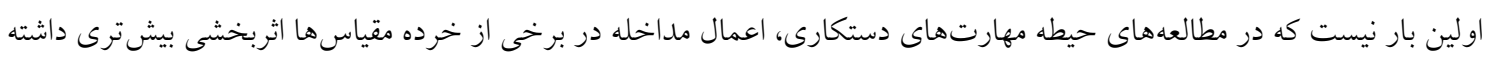

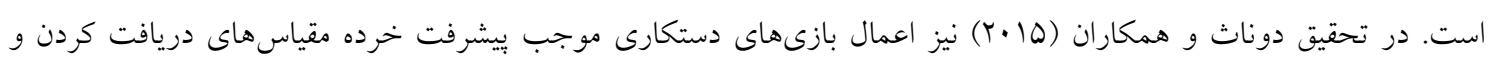

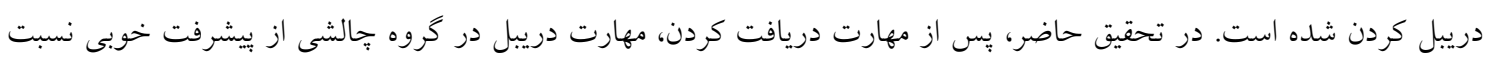
به كروه غير جالشى برخوردار است. اما اين بيشرفت معنىدار نيست. اينطور به نظر مىرسد با توجه به اين كه مهارتهايى مانند

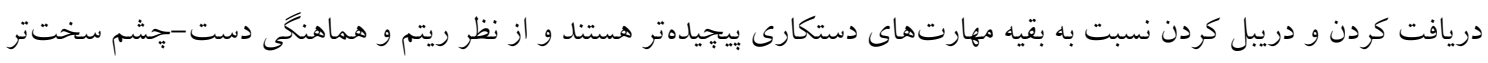
هستند (Y )، اعمال سختى تكليف و استفاده از مداخلههاى نقطه جالش، موجب توسعه بيشتر اين مهارتها مى گردد. مهارت

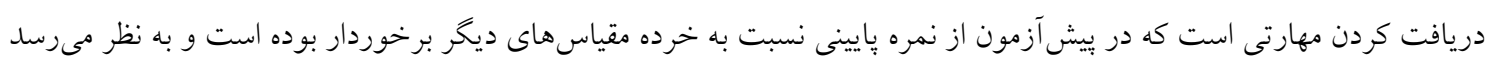

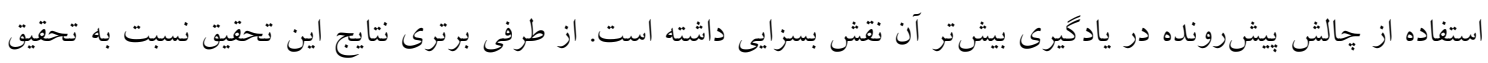

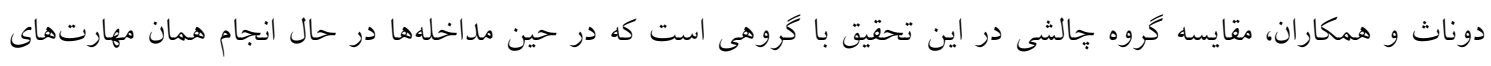
بنيادى دستكارى بودهاند و براى نمايش تغييرات دو گروه اثر متغير مستقل مىبايستى بسيار قوى باشد اين در حالى است كه در

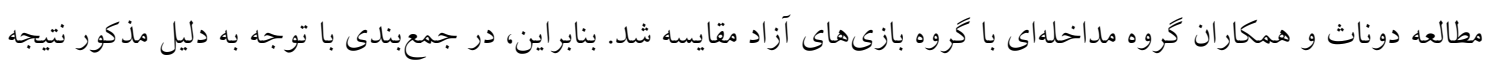

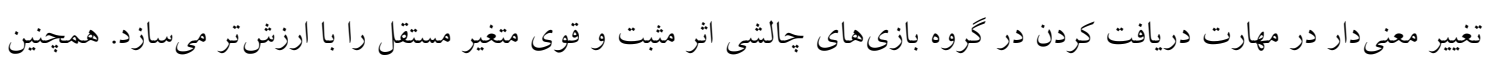

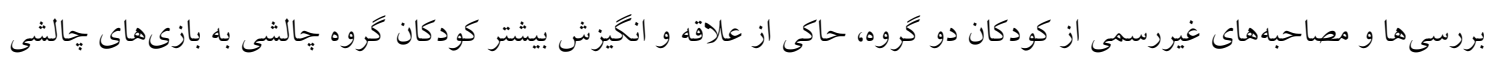
بوده است.

در خصوص تحقيق حاضر شايان ذكر است كه اين مطالعه جزء معدود مطالعهها حوزه جارجوب نظرى نقطه جالش است كه سختى

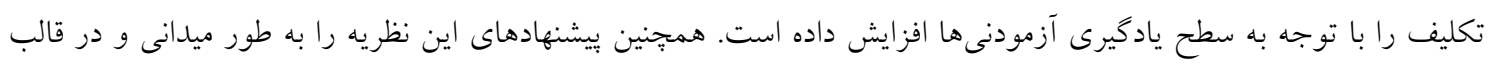

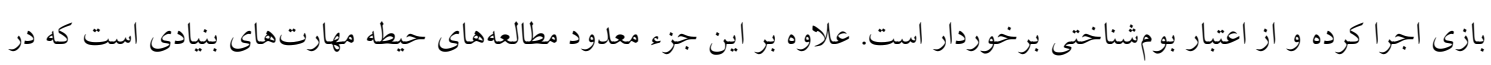


طراحى مداخلهها از يشتوانه نظرى بهره جسته است. همجنين نوع بازى، زمان هر بازى و نحوه اجرا آنها را به طور دقيق و واضح بيان كرده است. با توجه به اين كه بيشتر مداخلههاى مهارتهاى بنيادى بر روى كودكان داراى مشكلات رشد حركتى انجام شده بهاه است اين تحقيق جزء مطالعههايى است كه بر روى كودكان سالم انجام شده است. اما بدون شك تحقيق حاضر داراى محدوديت-

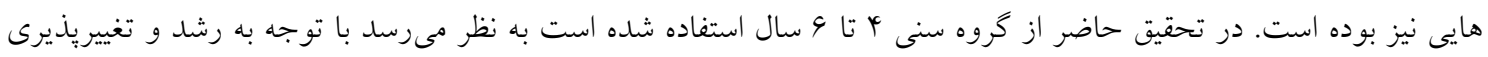

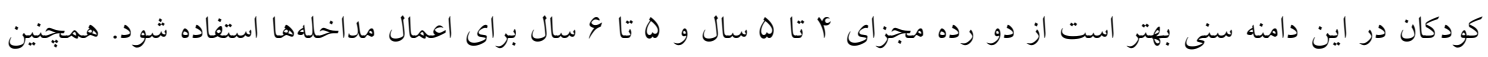
همانطور كه ديلده شد اثر مداخلهها بر خرده مقياسهاى دستكارى به طور متفاوت عمل مى كند استفاده از خرده مقياسها به طور

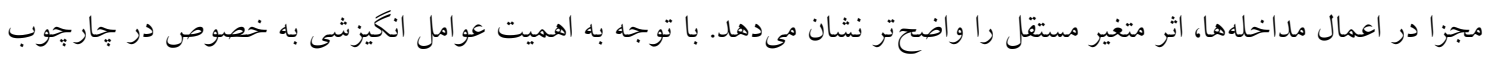

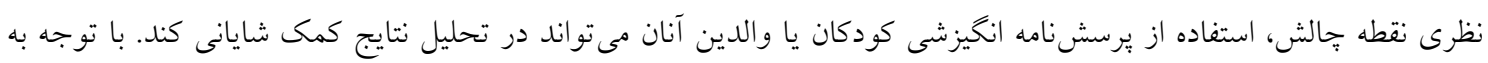
محدوديت تحقيق حاضر در تعداد آزمودنى ثابت، تعداد آزمودنىهاى بيشتر مىتواند موجب ارتقاء سطح تحقيق كردد. به طور كلى مىتوان نتايج تحقيق حاضر را در دو سطح نظرى و كاربردى جمعبندى كرد. نتيجه كيرى نظرى كه مى توان كرفت اين

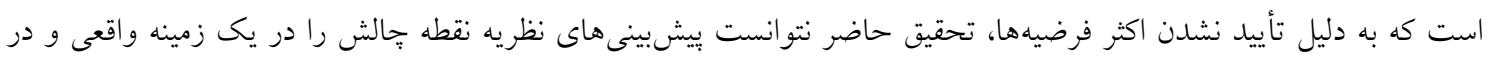

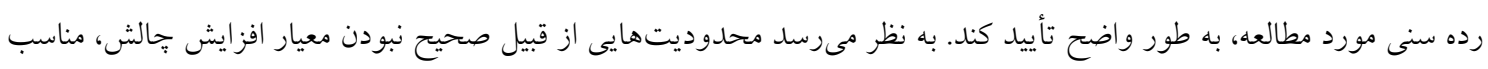

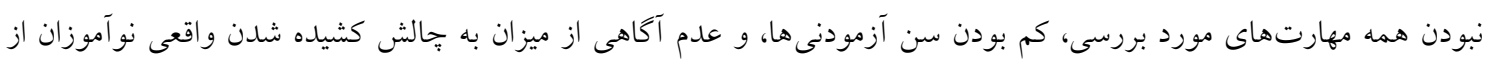

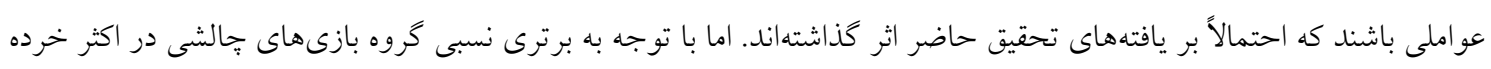

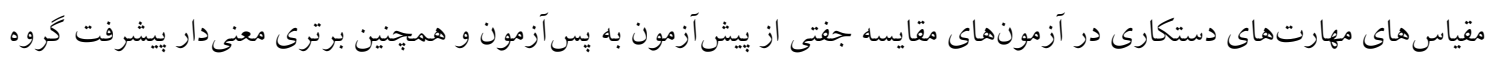

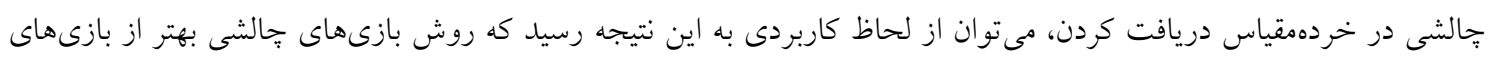

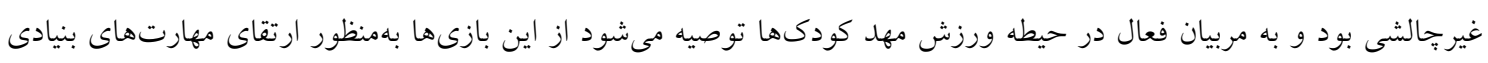

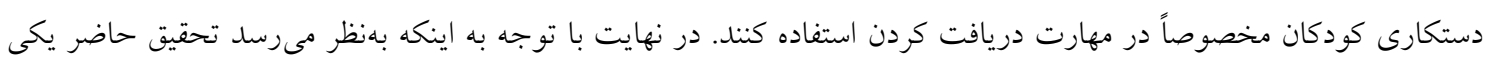

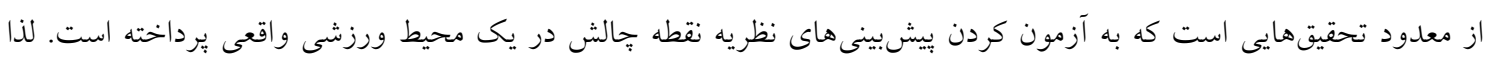

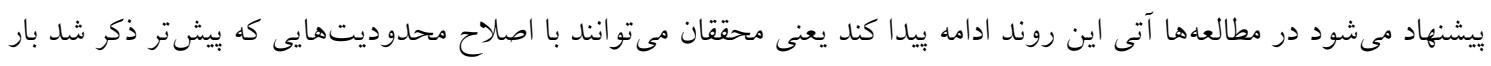

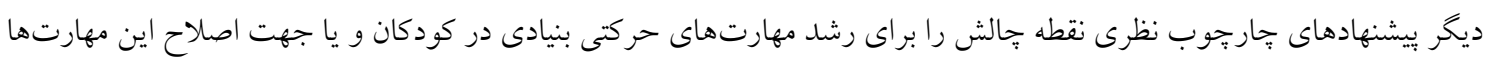

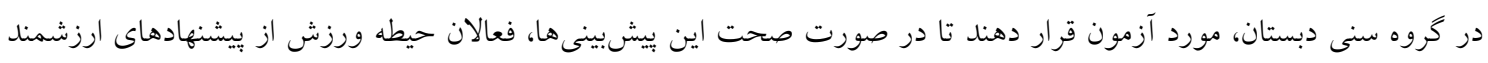
اين نظر يهها بى بهره نمانند.

\section{منابع}

1. Barnett LM, Morgan PJ, van Beurden E, Beard JR. Perceived sports competence mediates the relationship between childhood motor skill proficiency and adolescent physical activity and fitness: a longitudinal assessment. International journal of behavioral nutrition and physical activity. 2008;5(1):40.

2. Zask A, Barnett LM, Rose L, Brooks LO, Molyneux M, Hughes D, et al. Three year follow-up of an early childhood intervention: is movement skill sustained. Int J Behav Nutr Phys Act. 2012;9(1):127.

3. Gallahue DL, Ozmun JC, Goodway J. Understanding motor development: Infants, children, adolescents, adults: Mcgraw-hill Boston; 2006.

4. Logan S, Robinson L, Wilson A, Lucas W. Getting the fundamentals of movement: a meta-analysis of the effectiveness of motor skill interventions in children. Child: care, health and development. 2012;38(3):305-15.

5. Guadagnoli MA, Lee TD. Challenge point: a framework for conceptualizing the effects of various practice

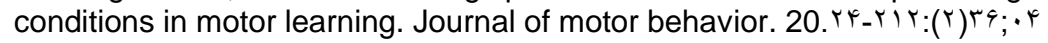

6. Guadagnoli M, Morin MP, Dubrowski A. The application of the challenge point framework in medical education. Medical education. 2012;46(5):447-53.

7. Hitchcock ER, Mcallister Byun T. Enhancing generalisation in biofeedback intervention using the challenge point framework: A case study. Clinical linguistics \& phonetics. 2015;29(1):59-75.

8. Pesce C, Crova C, Marchetti R, Struzzolino I, Masci I, Vannozzi G, et al. Searching for cognitively optimal challenge point in physical activity for children with typical and atypical motor development. Mental Health and Physical Activity. 2013;6(3):172-80.

9. Cantin N, Ryan J, Polatajko HJ. Impact of task difficulty and motor ability on visual-motor task performance of children with and without developmental coordination disorder. Human movement science. 2014;34:217-32.

10. Sanli EA, Lee TD. What Roles Do Errors Serve in Motor Skill Learning? An Examination of Two Theoretical Predictions. Journal of motor behavior. 2014;46(5):329-37. 
11. Sanli EA, Lee TD. Nominal and functional task difficulty in skill acquisition: Effects on performance in two tests of transfer. Human movement science. 2015;41:218-29.

12. Donath L, Faude O, Hagmann S, Roth R, Zahner L. Fundamental movement skills in preschoolers: a randomized controlled trial targeting object control proficiency. Child: care, health and development. 2015.

13. Kerkez FI, Robinson L. The Efficacy of Motor Skill Interventions among Turkish Preschoolers: A Review of the Turkish Literature and Recommendations. Middle-East Journal of Scientific Research. 2013;16(6):769-74.

14. Riethmuller AM, Jones RA, Okely AD. Efficacy of interventions to improve motor development in young children: a systematic review. Pediatrics. 2009;124(4):e782-e92.

15. Hardy LL, King L, Farrell L, Macniven R, Howlett S. Fundamental movement skills among Australian preschool children. Journal of Science and Medicine in Sport. 2010;13(5):503-8.

16. van Beurden $E$, Zask A, Barnett $L$, Dietrich U. Fundamental movement skills-how do primary school children perform? The 'Move it Groove it'program in rural Australia. Journal of Science and Medicine in Sport. 2002;5(3):244-52.

17. APACHE RG. ACTIVITY-BASED INTERVENTION IN MOTOR SKILL DEVELOPMENT 1. Perceptual and motor skills. 2005;100(3c):1.r... ll

18. Haywood K, Getchell N. Life span motor development: Human kinetics; 2009

19. Lee M, Chow J, Komar J, Tan C, Button C. Nonlinear Pedagogy: An Effective Approach to Cater for Individual Differences in Learning a. 2014.

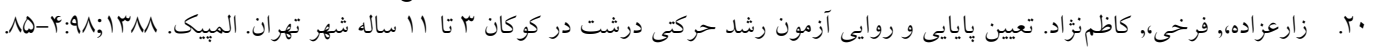

21. Dienstmann R. Games for motor learning: Human Kinetics; 2008.

22. Rigoli D, Piek JP, Kane R, Oosterlaan J. Motor coordination, working memory, and academic achievement in a normative adolescent sample: Testing a mediation model. Archives of clinical neuropsychology. 2012;27(7):766-80. 